\title{
Accounting Mismatch of Enterprise Assets and Enterprise Liabilities
}

\author{
Ruting Yang* \\ International Department, Zhejiang Ruian High School, Rui'an, 325200, China \\ *Corresponding Author's Email: jessicayang.razx@outlook.com
}

\begin{abstract}
The difference in measurement basis makes companies have serious accounting mismatch problems when accounting for FA (Financial Assets) and Fl (financial liabilities), which leads to the instability of owner's equity accounts and income statement accounts. Fair value measurement has the same measurement characteristics used to calculate the liabilities and assets of enterprises, and its proposal and application can well improve the problem of accounting mismatches. Therefore, the purpose of this article is to study the accounting mismatch between corporate assets and corporate liabilities. This article analyzes the related concepts of corporate financial accounting and compares the new and old financial instruments. This article summarizes the consequences caused by the accounting mismatch of corporate assets and corporate liabilities, and proposes a plan to alleviate the accounting mismatch.
\end{abstract}

Keywords: Fair Value Stratified Measurement, Accounting Mismatch, Corporate Assets, Corporate Liabilities

\section{INTRODUCTION}

Because different measurement characteristics are adopted when accounting for corporate assets and liabilities, which are displayed on the corporate financial statements, it will lead to mismatches of accounting information [1-2]. This happens to reflect the application of fair value imbalance in corporate financial assets and financial liabilities [3]. On the one hand, the problem of accounting mismatches will affect the financial indicators of the enterprise and the value evaluation of the enterprise; on the other hand, it will also affect the supervision and management of the company by the supervisory authority, and affect the market operating environment [4-5]. Therefore, it is urgent to find a way to solve the problem of accounting mismatch.

Regarding the research on corporate assets, liabilities and accounting mismatches, many scholars at home and abroad have conducted multi-faceted discussions on them. For example, Bonner $\mathrm{M}$ used monsanto as the research object to study the company's influence liabilities [6]; Starting from the related concepts of corporate liabilities, Zhou Q studied the company's credit risk [7]; Chen J explored whether the normal process of corporate value diffusion can improve the performance of structured companies' debt pricing methods [8]; Barbosa L conducts research on business cycle and tax liabilities as decisive factors of corporate credit risk [9]. It can be seen that since the reform of the new accounting standards, the impact of corporate liabilities, assets, and accounting mismatches has attracted much attention. Therefore, this article's research on the accounting mismatch between corporate assets and corporate liabilities is of great significance.

This article focuses on the accounting mismatch between corporate assets and corporate liabilities. This article first analyzes the related concepts of corporate financial accounting and compares the old and new financial instruments, including the classification of FA in the old accounting standards and the classification of financial instruments in the new financial accounting standards. Then, it analyzes the consequences caused by the accounting mismatch of corporate assets and corporate liabilities, and finally proposes a plan to alleviate the accounting mismatch.

\section{CORPORATE FINANCIAL ACCOUNTING STANDARDS}

\subsection{Financial investment coefficient and financial liability coefficient}

Before understanding the calculation method of FA and liabilities, first define the financial investment 
coefficient and financial liability coefficient. The financial investment coefficient $a_{i j}$ represents the proportion of the financial investment of the $\mathrm{j}$-th sector to the $\mathrm{i}$-th sector in the total investment of the $\mathrm{j}$-th sector, and the calculation method is shown in formula (1):

$$
a_{i j}=w_{i j} / g_{j}
$$

The financial liability coefficient $b_{i j}$ represents the proportion of the $\mathrm{Fl}$ obtained by the $\mathrm{i}$-th sector from the $\mathrm{j}$-th sector in the total liabilities of the $\mathrm{i}$-th sector. The calculation method is shown in formula (2):

$$
b_{i j}=w_{i j} / g_{i}
$$

Table 1. Financial asset classification standards under the old accounting standards

\begin{tabular}{|c|c|}
\hline Classification of FA & Classification standard \\
\hline $\begin{array}{c}\text { Transactional FA or companies designated } \\
\text { as FA that are measured at fair value and } \\
\text { whose changes are included in the current } \\
\text { profit and loss }\end{array}$ & $\begin{array}{c}\text { For financial investment assets held for } \\
\text { trading, the purpose of holding is to } \\
\text { trade frequently and ultimately earn the } \\
\text { difference. }\end{array}$ \\
\hline FA held to maturity investment & $\begin{array}{c}\text { The enterprise has the ability to hold } \\
\text { the financial asset to the maturity date. }\end{array}$ \\
\hline Loan or receivable & $\begin{array}{c}\text { Recycling finance is fixed or } \\
\text { determinable, and the purpose is not } \\
\text { short-term sales. }\end{array}$ \\
\hline Available-for-sale FA & $\begin{array}{c}\text { FA or designated FA other than the } \\
\text { above three categories are all-round } \\
\text { items of FA. }\end{array}$ \\
\hline
\end{tabular}

In the old financial instrument standards, the classification of financial instruments needs to be reclassified strictly in accordance with document requirements. Only when certain conditions are met, "hold-to-maturity investments" can be reclassified as "available-for-sale FA." The old standard asset reclassification regulations are shown in Figure 1:

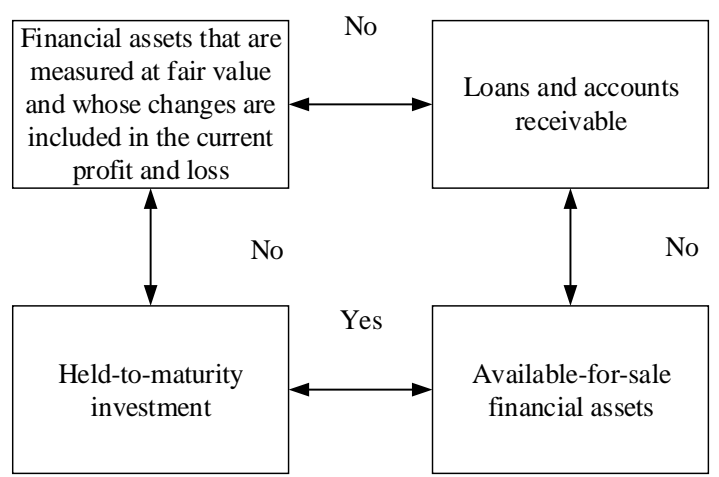

Figure 1. Logical framework diagram of important classifications in the old accounting standards

\subsection{The division of FA in the old accounting standards}

Before the Ministry of Finance announced the new accounting standards, the classification of financial instruments of Chinese enterprises was classified and measured in accordance with the four categories in the old standards. The classification method of old financial instruments is very simple and subjective, and the classification and measurement of the financial instruments held by the enterprise itself cannot truly reflect the objective content of the current financial instruments [10-11]. The criteria for classifying financial instruments under the old standards are shown in Table 1.

\subsection{Classification of financial instruments under the new financial accounting standards}

The new financial accounting standards regulate the classification and measurement of financial instruments, and define standards for the fair value measurement of financial instruments. At this time, the four categories have become three categories, and the model of impairment provision has changed. The reclassification of the three types of financial instruments is shown in Figure 2.

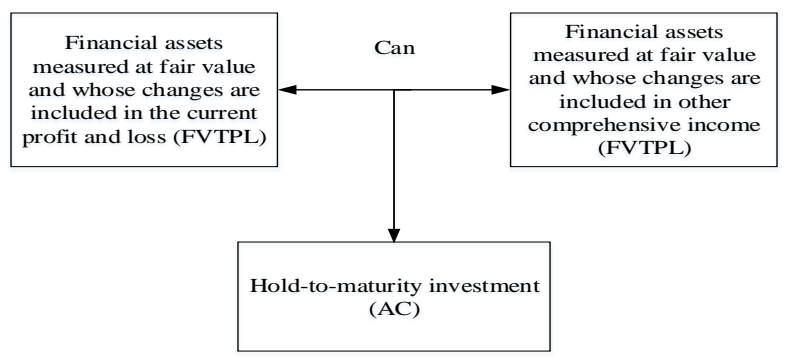

Figure 2. Logic diagram of important classification of financial instruments in the new standard (CAS22) 


\section{ECONOMIC CONSEQUENCES OF THE MISMATCH OF THE FA AND FL OF THE ENTERPRISE}

\subsection{Trigger changes in solvency and accounting profits}

The solvency of a company mainly refers to its ability to repay its debts, especially whether the company has enough assets to offset its debts [12]. Therefore, if a different measurement basis is used for $\mathrm{FA}$ and $\mathrm{Fl}$, it will directly affect the calculation of the corporate solvency ratio. Fl and FA are not only affected by changes in interest rates, but also by exchange rate changes, corporate investment and other factors. If the company's accounting profits increase, the company's solvency capital will also increase.

\subsection{Distortion of accounting information, misleading users of accounting information}

In life insurance companies, accounting mismatches can have extremely serious consequences. Because the information sources of company shareholders and policy holders and even creditors are not consistent, the information obtained does not match, decision makers will refer to the company's financial statements before making important decisions. If the book value of the company's assets and liabilities fluctuates significantly or does not match, it will lead to accounting mismatches, distortion of the information in the financial statements, and erroneous decisions for those who refer to the financial statements.

\subsection{Influencing investors' market judgment}

Accounting mismatches caused by changes in measurement methods have a greater impact on the volatility of profits; if $\mathrm{Fl}$ and FA are measured at fair value, the standard deviation of profits in each period will be reduced to varying degrees. Obviously, the unified fair value measurement method of corporate $\mathrm{Fl}$ and $\mathrm{FA}$ can reduce the range of profit fluctuations. However, as long as there is an accounting mismatch, Fl will fluctuate greatly along with the fluctuation of the market economy, leading to continuous changes in the level of profit in various periods. Moreover, these changes cannot truly reflect the actual changes in corporate liabilities and mislead investors' judgments on the market.

\section{PLAN TO ALLEViate THE ACCOUNTING MISMATCH OF THE FA AND FL OF THE ENTERPRISE}

\subsection{Change the asset-liability allocation strategy}

The new financial instrument standards emphasize the use of contract terms and business models as the reference point and basis for classifying financial asset types. Therefore, companies should change their assetliability allocation strategy. The specific methods are as follows:

First, reduce the proportion of equity assets in the allocation of corporate asset classes, increase the number of fixed income assets such as debt, pay attention to changes in the external environment in a timely manner, and increase the proportion of alternative investment assets accordingly;

Second, increase medium- and long-term equity investments in equity assets, reduce the impact of equity assets on profits, increase equity asset investments with more dividends to increase the rate of invest in treasury bonds with short-term and low credit risks, strengthen risk management and enhance solvency;

Third, in terms of alternative investment, companies should appropriately increase the proportion of real estate, property and other assets with better market returns based on market performance, pay attention to the balance of risks and returns, and achieve a good match between corporate assets and liabilities.

\subsection{Strengthen the use of fair value of Fl}

The consistency of the measurement basis of assets and liabilities can fundamentally reduce the occurrence of accounting mismatch problems. In order to ensure the accuracy of the calculation results of $\mathrm{Fl}$, companies can introduce fair value into calculations, ensure settlement efficiency, provide companies with more accurate financial information, help companies make financial decisions, avoid human errors or errors, and reduce the company's operating costs. Financial risk, to avoid accounting mismatches caused by fluctuations in profit and loss.

\subsection{Fully use the fair value measurement model}

Under the fair value model, hedging accounting will no longer exist, and the changes in the funds of the hedged items of the enterprise can be fully recorded by the method of fair value measurement, minus the link of verification and adjustment of the hedging relationship, so as to directly avoid the impact of the period on the profit and loss of the enterprise. When the issue of fair value rights is resolved, companies can not only reduce the cost of financial information disclosure, but also optimize the corporate financial personnel system, reduce unnecessary expenses, and avoid disputes among corporate staff on issues related to fair value selection. 


\subsection{Improve the professional judgment ability of accountants}

Under inactive market conditions, the application of the second and third levels of fair value measurement provides accountants with more flexible choices. Correspondingly, higher requirements are put forward on the professional quality of accountants. Therefore, it is necessary to strengthen the training of accountants' professional judgment manpower. The specific methods are:

First of all, relevant institutions should improve the knowledge and ability of accountants in fair value valuation through various methods such as training and learning lectures. At the same time, relevant institutions should also reasonably guide accountants to understand and learn professional judgments, actively use professional judgments, and conduct business guidance on judgment issues in the use of fair value to help improve the professional judgment of financial workers.

\subsection{Strengthen inter-departmental coordination and cooperation, and establish a horizontal communication mechanism}

The implementation of the new financial instrument standards requires the participation of multiple departments of the enterprise, and only one department is not enough. For enterprises, risk management departments, business departments, and financial departments should all be involved. Only with the joint efforts of various departments, companies can more accurately carry out the accounting of FA and Fl.

At the same time, corporate accounting should be more adept at using front-end and mid-end information, such as risk information and transaction information. Because the reliability of asset recognition, measurement results and classification depend to a large extent on the quality of the work of the business department and the risk department.

In addition, companies need to establish a new accounting management and control model to achieve the coverage of the initial and terminal systems of accounting standards, and to optimize the internal communication mechanism for business, risk and accounting management, based on the facts, and establish an objective assessment of assets and liabilities. That is to move the node of accounting and financial accounting control forward to the business management and risk management links, to ensure that all management links are seamlessly connected with the new standards, so as to achieve the unification of the measurement attributes of corporate assets and liabilities.

\section{CONCLUSION}

In order to enable fair value measurement to be more widely used in practice, the IASB and FASB have been committed to the improvement of relevant standards. The implementation of the new financial instrument standards has reduced the large fluctuations in profits. In order to maintain the stability of corporate profits, reduce the fluctuations in profits, and enhance solvency, fair value must be used more in the company's assets and liabilities, and full fair value the use of will be the future trend. Therefore, through systematic research, this article has completed the following tasks: analyzes the related concepts of corporate financial accounting, compares the new and old financial instruments from the difference in classification methods; analyzes the consequences of the accounting mismatch of corporate assets and corporate liabilities; propose a plan to reduce the problem of accounting mismatch, and provide reference suggestions for enterprises to reduce the problem of accounting mismatch.

\section{REFERENCES}

[1] Herz B, Rens T V. Accounting for mismatch employment[J]. The Warwick Economics Research Paper Series (TWERPS), 2019.

[2] Avanzi B, Henriksen L, Wong B . ON THE DISTRIBUTION OF THE EXCEDENTS OF FUNDS WITH ASSETS AND LIABILITIES IN PRESENCE OF SOLVENCY AND RECOVERY REQUIREMENTS[J]. Astin Bulletin, 2018, 48(2):1-26.

[3] Marco F, Jonathan J. Liquid Assets? The Short-Run Liabilities of Binge Drinking $[\mathrm{J}]$. The Economic Journal, 2018(621):621.

[4] Cade N L, Koonce L, Mendoza K I, et al. Assets and Liabilities: When Do They Exist?[J]. Contemporary Accounting Research, 2019.

[5] Benedikt H, Thijs V R. Accounting for Mismatch Unemployment[J]. Journal of the European Economic Association, 2019.

[6] Bonner M. From the Boardroom to the Courtroom: Monsanto Corporate Influence and Liabilities. 2020.

[7] Zhou Q, Yang J J, Wu W X . Pricing Vulnerable Options with Correlated Credit Risk Under Jumpdiffusion Processes When Corporate Liabilities Are Random[J]. Acta Mathematicae Applicatae Sinica, English Series, 2019, 35(2):305-318.

[8] Chen J. Can a Normal Firm Value Diffusion Process Improve the Performance of the Structural Approach to Pricing Corporate Liabilities?[J]. SSRN Electronic Journal, 2016. 
[9] Barbosa L, Pinho P. Operational cycle and tax liabilities as determinants of corporate credit risk[J]. Economic Bulletin and Financial Stability Report Articles and Banco de Portugal Economic Studies, 2017.

[10] Xie H B, Ding L F. Will the Group's Concentrated Liabilities Affect Corporate Innovation[J]. Journal of Guangdong University of Finance \& Economics, 2019.

[11] Fitri T, Sulistiyo A B, Roziq A. Influence Policy Liabilities, Size, Growth Corporate and Profitability and Value of the Company in the Agricultural Sector in Indonesia. 2018.

[12] Shi W, Gao C, Aguilera R V. The Liabilities of Foreign Institutional Ownership: Managing Political Dependence Through Corporate Political Spending[J]. Strategic Management Journal, 2020. 